\title{
Analysis of the Effect of Information Quality and Easiness on Satisfaction through User Trust of SIAKAD University of Merdeka Malang, Indonesia
}

\author{
L. Taufan Prasetya ${ }^{1}$, Dwi Arman Prasetya ${ }^{2}$, Nanik Sisharini ${ }^{2}$ \\ ${ }^{1}$ Student in Magister of Management, University of Merdeka Malang, Indonesia \\ ${ }^{2}$ Lecturer of Masters in Management Information System, University of Merdeka Malang, Indonesia
}

\begin{abstract}
This study aims to analyze the influence of information quality and easiness on trust, to analyze the influence of information quality and easiness on user satisfaction, to analyze the effect of trust on user satisfaction and to analyze information quality and easiness on user satisfaction through the trust of SIAKAD Unmer Malang. The sample in this study were 75 students. The data analysis technique used path analysis. Based on the results of the analysis, it shows that the quality of information and easiness have an effect on trust, which means that quality SIAKAD information supported by easiness of operation can increasiness trust. Information quality and easiness have an effect on user satisfaction. This means that user satisfaction can be built through the provision of quality information and easiness of use of SIAKAD. Trust affects user satisfaction, which means thatuser trust can build user satisfaction because easiness of use is reflected in being satisfied with the information presented at SIAKAD making it easier for activities. Trust mediates the effect of information quality and easiness on user satisfaction. This means that user satisfaction can be built if users feel that the information presented is of high quality and makes it easy to operate SIAKAD.
\end{abstract}

Keywords: Information Quality, Easiness, Trust, Satisfaction.

\section{INTRODUCTION}

Information technology is one element that plays an important role in today's development, especially when someone leads and manages an organization. By using information technology, every administrative and management activity of an organization can be controlled and managed properly. This condition can be better if combined with the internet. The combination of these two elements can make the performance of an organization more efficient and effective. One example of an organization is a university in which there are students and lecturers.

Various types of information related to tertiary institutions must be known properly, correctly, and quickly to students and lecturers. This has a major effect on several activities in higher education such as: new student admission activities, KRS, lecture process, payment of tuition fees, management of student and lecturer data, and others. In order for all sources of information to be managed properly, a service is needed that can unify all information into a source of information that can be seen and known by students and lecturers at higher education institutions. One of the services that can integrate all information in higher education is Academic Information System (SIAKAD). SIAKAD is an academic information system created to provide facilities for university users in carrying out activities related to campus online. This system can also function as a support that can function to analyze data. In addition, the management of higher education can make decisions related to campus easier.

Petter et al. (2013) argued that information quality is a characteristic of output displayed in an information system, which includes web pages and report management. This is to assess how well the output obtained from the information system used [1]. William (2012) revealed that the quality of information is measured by several indicators including relevance, timeliness, completeness, accuracy, and consistency [2]. The better the quality of information in a system, the higher the level of user satisfaction in the system. Almazan, et al (2017) state that the findings of empirical analysis show that the quality of information is the most important in determining user satisfaction [3]. Because users consider information systems that can inform the accuracy and availability of information as elements of a successful system implementation.

SIAKAD makes it easy for users to always be able to monitor the development of every academic activity on campus, so that every process can be carried out efficiently and effectively. With the campus SIAKAD, it makes it easy for users to monitor every activity development in the campus environment. Mahardika and Basuki (2011) suggest that the perception of easiness of use provides several indicators of an information system consisting of time efficiency in use, the appearance of the site is easy to 
understand, adds skills in using it, and is easy to learn. [4]. If the level of easiness of use for users in using SIAKAD is relatively high, trust will also be high and affect user satisfaction. Research results by Putra et al. (2016) [5] and Rahmad et al. (2017) [6] found that easiness had an effect on trust. Research results of Ginting and Marlina (2017) [7], Wijaya and Kempa (2018) [8] found that easiness had an effect on satisfaction.

The objectives to be achieved are: to describe the quality of information, easiness, trust and satisfaction of users, to analyze the influence of information quality and easiness on trust, to analyze the influence of information quality and easiness on user satisfaction, to analyze the effect of trust on user satisfaction and to analyze information quality and easiness to user satisfaction through the trust of SIAKAD Unmer Malang.

\section{LITERATURE REVIEW}

\subsection{Quality of Information}

Kadir (2010: 46) states "The quality of information is used to state good information, and can also be analogized to being the pillars of a building and determining whether or not it is good in decision making" [9]. Furthermore, DeLone and McLean (2003) revealed that the quality of information assesses the quality of the output of the information system, namely the quality obtained from the information system, especially in the form of various reports [10]. Petter et al. (2013) suggested information quality, namely the characteristics of the output displayed in the information system consisting of web pages and report management [1]. Furthermore, Bodnar and Hopwood, translated by Saputra and Setiawati (2010: 15), state that "Information quality is the level at which data that has been processed by an information system has meaning for its users, which can manifest useful values and facts" [11].

DeLone and McLean (2003) argue that quality is strongly influenced by four things, including: Relevant, information should provide usefulness for users [10]. The relevance of information for each user is different; It is accurate, there are no errors in information, and the purpose should be clear. Inaccuracies can occur because the source of the information has interference or intentionality so that it can change or destroy the original data; Be on time, the information needed should be on time. Information that is slow has no value, so if it is used as a reference in making decisions, this information can have a fatal impact on actions and decisions. This situation results in a high value of information, so that the speed of processing, obtaining, and sending requires the latest and reliable technology, the information displayed in the information system should be believed so that it can be used by users directly.

\subsection{Easiness}

Easiness according to Widjana in Pambudi et al (2014) is an individual's belief that using an information technology system will not be a hassle or require a large amount of effort when used [12]. Furthermore, Davis in Priambodo et al. (2016) defines easiness as the level where users believe that the use of technology is easy and does not require hard effort from its users [13]. The concept includes clarity of the purpose of using technology and easiness of use of the system for purposes in accordance with user expectations. Goodwin in Armanda et al (2015), the intensity of use and interaction between users and the system can also show easiness of use [14]. The more frequently used systems indicate that they are more familiar, easier to operate and easier to use by users. When consumers think a product is easy to use, users will feel the usefulness of the product in order to fulfill their wishes and users.Easiness of indicators according to Lee et al. (2010) explain as follows: information technology is very easy to learn, easy to skilled in the use of information technology and information technology is very easy to operate [15].

\subsection{Trust}

Trust is the belief of one party regarding the intentions and behavior of the other party. Thus, consumer confidence is the consumer's expectation that service providers can be trusted or relied upon in keeping their promises(Sirdeshmukh et al., 2002) [16]. Sam and Tahir (2010) argue that trust is a characteristic that is determined by factors of uncertainty, instability, and dependence [17]. Trust is understood as a dimension of a relationship that determines the degree to which a party feels that they can trust the integrity of the promises offered by the other party. Trust in this case is a feeling to be able to trust the other party for all the promises that have been given.

Mayer et al. (2005: 712) defines trust is a person's willingness to be sensitive to the actions of others based on the expectation that other people will perform certain actions on those who believe in them, without depending on their ability to monitor and control them [18]. There are three factors that shape a person's trust in others according to Mayer et al. (2005: 721), namely; ability (ability), kindness (benevolence) and integrity (integrity) [18].

\subsection{User Satisfaction}

User satisfaction is the feeling of the user after using the information system. Overall user satisfaction is influenced by service quality, system quality and information quality. So that the instrument used in assessing the level of user satisfaction is 
paying attention to the level of satisfaction associated with the output produced, and supporting services from the website of the system provider (Petter et al., 2013) [1].

Kotler and Armstrong (2014: 150) reveal that satisfaction is feelings of disappointment or pleasure that arise when comparing the performance (results) of the product in mind against the expected performance (or results) [19]. The assessment of customer satisfaction has three other forms including: positive disconfirmation, which is performance that is better than expectations; simple confirmation, is the expectation equal to the performance; negative disconfirmation, is a higher expectation than performance. Then from DeLone and McLean (2003), there are five indicators in assessing users, including: Content, namely user satisfaction seen from its content. The contents can be in the form of modules and functions used by the user as well as information obtained that matches the user's needs; Accurate, namely user satisfaction with data accuracy when receiving input and then processing it into information; Format, namely user satisfaction in terms of the input obtained; easiness of use, namely user satisfaction in terms of user easiness in using the system, for example processing data, entering data, and obtaining the necessary information; and timelines, namely user satisfaction in terms of the timeliness of the system in presenting data and information required by the user [10].

\subsection{Hypothesis}

The hypothesis in this study are:

H1 : Quality of information and easiness has an effect on trust.

H2 : Quality of information and easiness affects user satisfaction.

H3 : Trust has an effect on user satisfaction.

H4 : Quality of information and easiness affects user satisfaction through trust.

\section{RESEARCH METHODS}

\subsection{Definition Operational Variables}

a. Quality of information

Information quality, namely the quality of information output that is produced by the information system for use. Indicators of information quality include: relevant, accurate, timely and reliable.

b. Easiness

Kemuahan is the user feels that technology is easy to understand and easy to operate. The indicators of easiness are as follows: easy to learn, easy to use, and easy to operate.

c. Trust

Trust is the user's belief in using information SIAKAD. The indicators used in trust are as follows: ability, kindness and integrity.

d. User satisfaction

User satisfaction is the impression a person gives from the experience of using information system outputs. The indicators used are: Format, Content, Easiness of use, Timeliness and Accuracy.

\subsection{Population and Sampling Techniques}

The population in this study were all students of Management Masters Program at Merdeka University Malang, amounting to 306 students. The number of samples in this study was calculated using the Slovin formula, in order to obtain a sample of 75 students. The sampling technique uses simple random sampling, which is called simple or simple because the sampling of members of the population is carried out irregularly, regardless of the strata contained in the study population. The questionnaire used in this study uses digital assistance, namely Google Form. Google forms are useful tools to help create surveys and gather information easily and efficiently. This application is used to make it easier to distribute questionnaires and more efficient, namely by entering the questionnaire questions via Google Form and later distributed digitally to research respondents. 


\subsection{Data analysis technique}

The method of analyzing data in this study was carried out by techniques including: Descriptive Analysis and Structural Equation Modeling is better known as SEM. The Structural Equation Model is a combination of factor analysis, regression and path analysis. The structural equation model can be tested to determine the value of direct, indirect and total effects between exogenous and endogenous variables. Linear Regression Analysis as an analytical tool for testing structural equation models and proving research hypotheses using the SPSS statistical program, with the following equation:

$\mathrm{Y}_{1}=\mathrm{b}_{1} \mathrm{X} 1+\mathrm{b} 2 \mathrm{X} 2+\mathrm{e} 1$

$\mathrm{Y}_{2}=\mathrm{b}_{3} \mathrm{X} 1+\mathrm{b} 4 \mathrm{X} 2+\mathrm{b} 5 \mathrm{Y} 1+\mathrm{e} 2$

\section{RESULTS AND DISCUSSION}

\subsection{Result Analysis}

To determine the effect of information quality, easiness and trust on user trust and satisfaction, directly or indirectly, using multiple linear regression methods. This statistical test can be done using the standard beta coefficient ( $\beta$ standard). If the value of $\beta$ is significant, then the path coefficient is significant. The insignificant path coefficient is discarded. The significance test can be done by comparing the significance of these pathways. If the significance value of the path coefficient is less from 0.05 then the coefficient is considered significant. Otherwise, if value significance coefficient greater than from 0.05 , it is considered insignificant. To see the effect of information quality and easiness on user satisfaction through confidence is served on Table 1 following.

Table 1. Summary of Results of the Direct, Indirect, and Total Influence Analysis of the Path Analysis

\begin{tabular}{|c|c|c|c|c|}
\hline Variable & Direct Effect & Prob & Indirect Effect & Total Effect \\
\hline Quality of information $\rightarrow$ Trust & 0.376 & $0.001 *$ & - & - \\
\hline Easiness $\rightarrow$ Trust & 0.419 & $0.000 *$ & - & - \\
\hline Quality of information $\rightarrow$ User satisfaction & 0.235 & $0.034 *$ & - & - \\
\hline Easiness $\rightarrow$ User satisfaction & 0.289 & $0.011 *$ & - & - \\
\hline Trust $\rightarrow$ User satisfaction & 0.368 & $0.001 *$ & - & - \\
\hline Quality of information $\rightarrow$ Trust $\rightarrow$ User satisfaction & 0.235 & - & $0.376 \times 0.368=0.138$ & 0.514 \\
\hline Easiness $\rightarrow$ Trust $\rightarrow$ User satisfaction & 0.289 & - & $0.419 \times 0.368=0.154$ & 0.573 \\
\hline
\end{tabular}

* significant at $\alpha 5 \%$

\subsection{Hypothesis test}

\section{a. Test Hypothesis 1}

Based on Table 1, the beta coefficient value of information quality is 0.376 and $\mathrm{p}$ value of 0.001 smaller from $\mathrm{p}=0.05(\alpha=$ $5 \%$ ), which means that the quality of information has a significant effect on trust. The value of the beta easiness coefficient is 0.419 and $p$ value amounting to 0,000 smaller from $p=0.05(\alpha=5 \%)$, which means that easiness has a significant effect on trust. Thus the hypothesis first one stated that the quality of information and easiness has a statistically tested effect on trustworthiness.

\section{Hypothesis Test 2}

Based on Table 1, the beta coefficient value of information quality is 0.235 and $\mathrm{p}$ value amounting to 0.034 smaller from $\mathrm{p}=$ $0.05(\alpha=5 \%)$, which means that the quality of information has a significant effect on user satisfaction. The value of the beta easiness coefficient is 0.289 and $p$ value amounting to 0.011 smaller from $p=0.05(\alpha=5 \%)$, which means that easiness has a significant effect on user satisfaction. Therefore the second hypothesis which is stated that the quality of information and easiness has a statistically significant effect on user satisfaction. 


\section{b. Test Hypothesis 3}

Based on Table 1, the confidence beta coefficient value is 0.368 and $p$ value of 0.001 smaller from $p=0.05$ ( $\alpha=5 \%$ ), which means that trust has a significant effect on user satisfaction, so that hypothesis third that stated that trust has a statistically significant effect on user satisfaction.

\section{c. Hypothesis Test 4}

Based on Table 1, the results of the analysis show that trust status is an intervening variable that can mediate the information quality variable, because the total effect value $(0.514)$ is greater than the direct effect $(0.235)$. Trust status is an intervening variable that can mediate the easiness variable on user satisfaction, because the total effect value $(0.573)$ is greater than the direct effect (0.289). Thus, the fourth hypothesis states that information quality and easiness affect user satisfaction through trust statistically tested.

Based on the description of hypothesis testing, the path model in path analysis is presented in Figure 1 below.

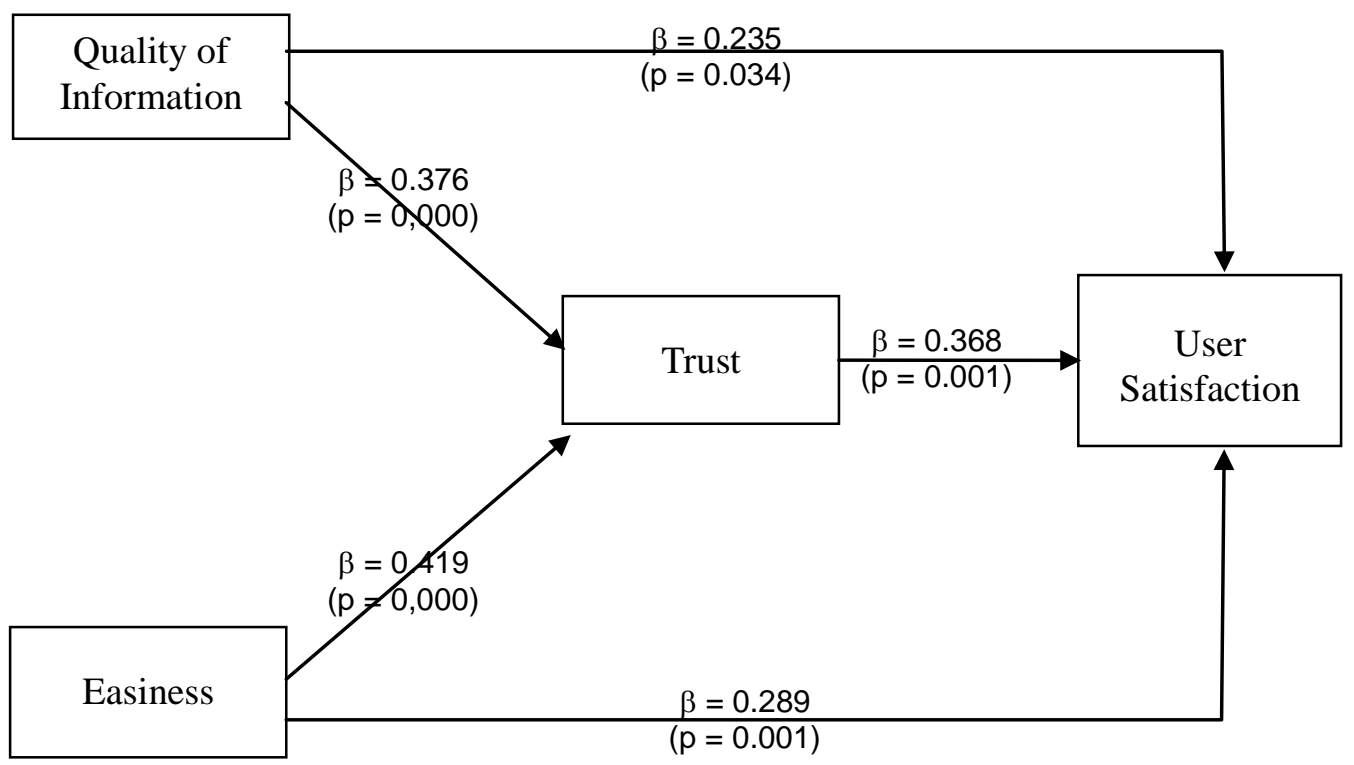

Figure 1. Path Analysis Results

Source : Primary data processed, 2021.

\subsection{Discussion}

\subsubsection{Effect of Information Quality and Easiness of Trust}

The quality of information has an effect on trust, which means that the quality of the information available in SIAKAD can increasiness user confidence. The quality of information that makes the biggest contribution to increasing trust is trustworthy, reflected in the trustworthy information presented by SIAKAD Unmer Malang, so that it can increasiness trust because SIAKAD helps students in financial services, helps students in academic services and makes it easier for students to manage KRS and others. The quality of information that is managed properly will give good results to fulfill user trust. If the service that the user feels is satisfying is what the user wants, it will be beneficial for the user.

Easiness has an effect on trust, which means that the higher the easiness with which SIAKAD can increasiness trust [20]. The use of SIAKAD is aimed at facilitating and accelerating the management of information starting from registering new students, filling KRS, viewing grades, important information, and class schedules. In addition, it is easy for students to obtain information without having to interact directly with the administration department because this information can be obtained by searching data through cellphones, laptops or computers connected online. As the opinion of Hadi et al. (2014) which states that easiness gives an indication that a system is designed not to make it difficult for users, but instead makes it easier for users to complete work [21]. In other words, users who use the system will work easier than users who do not use the system or work manually. The results of this study support Putra et al. (2016) which states that easiness affects trust [5]. 


\subsubsection{The Effect of Information Quality and Easiness on User Satisfaction}

User satisfaction is influenced by the quality of information, which means that the quality of information available at SIAKAD Unmer Malang causes user satisfaction to increasiness. The quality of information is timeliness, safe, relevant level, and provided with good information design on SIAKAD. Good quality information can increasiness user satisfaction. The measure of user satisfaction with information is reflected in the quality of information obtained from a system. If the user of the information system trusts the maximum information obtained from a system, the user can feel satisfied using the system used. As the opinion of DeLone and McLean (2003) which states that the quality of information assesses the quality of the output of the information system, namely the quality obtained by the information system, particularly the various tangible reports [10]. The higher the quality of information produced by an information system, system users will feel satisfaction when using the information because the information provided is best suited to user needs. The results of this study support Pawirosmarto (2016) [22], Ginting and Marlina (2017) [7], Utomo et al. (2017) [23], Wahyudi et al (2017) [24], Wijaya and Kempa (2018) [8] who found that the quality of information affects user satisfaction. Utomo et al. (2017) [23], Wahyudi et al (2017) [24], Wijaya and Kempa (2018) [8] who found that the quality of information affects user satisfaction. Utomo et al. (2017) [23], Wahyudi et al (2017) [24], Wijaya and Kempa (2018) [8] who found that the quality of information affects user satisfaction.

Easiness has an effect on user satisfaction, this shows that The easiness with which SIAKAD can build user satisfaction. Perceived easiness of use is the level where students believe that technology is easy to learn, easy to use and easy to operate. The element of easiness in using SIAKAD can help users feel satisfaction from using SIAKAD, because with easy use and operation, users can maximize the use of SIAKAD and feel the benefits of SIAKAD. SIAKAD which makes it easier for users in the teaching and learning process on campus. The results of this study support Ginting and Marlina (2017) [7] and Wijaya and Kempa (2018) [8] which state that easiness affects user satisfaction.

\subsection{The Effect of Trust on User Satisfaction}

Trust affects user satisfaction, which means that the higher the level of user trust in using SIAKAD can increasiness user satisfaction. User trust is basically a form of SIAKAD user support for the efforts made to get everything desired, through user trust will give Unmer Malang confidence to create user satisfaction. The indicator of trust that makes the greatest contribution to increasing user satisfaction is integrity, which is reflected in SIAKAD helping students in financial services, helping students in academic services and making it easier for students to manage KRS and others.

\subsection{The Influence of Information Quality and Easiness on User Satisfaction through Trust}

Trust is able to mediate the effect of information quality and easiness on user satisfaction. User trust is important for Unmer Malang, if the user is satisfied with the information provided by Unmer Malang and the user believes in using SIAKAD, the user will be satisfied. Trust is basically a psychological state of the user in carrying out activities, in this case the trust in using SIAKAD. Trust will provide support in using SIAKAD through internet media.Information quality and easiness can increasiness user satisfaction if it is supported by the user to feel confident in the information submitted to the user. Quality of information as output produced by Unmer Malang, quality of information can be relevant, accurate, timely and reliable. If the information produced is of high quality and easy to operate, users will feel more confident in the information obtained, so that it has an impact on increasing user satisfaction. As Petter et al. (2013) which states that user satisfaction is the feeling of the user after using an information system [1]. Overall user satisfaction is influenced by service quality, system quality and information quality.

\section{CONCLUSIONS AND SUGGESTIONS}

\section{a. Conclusion}

Based on research result and discussion that can be done drawn conclusions as the following:

1) The quality of information and easiness affect trust, which means that quality SIAKAD information supported by easiness of operation can increasiness trust.

2) Information quality and easiness have an effect on user satisfaction. This means that user satisfaction can be built through the provision of quality information and easiness of use of SIAKAD. 
3) Trust affects user satisfaction, which means that user trust can build user satisfaction because easiness of use is reflected in being satisfied with the information presented at SIAKAD making it easier for activities.

4) Trust mediates the effect of information quality and easiness on user satisfaction. This means that user satisfaction can be built if users feel that the information presented is of high quality and makes it easy to operate SIAKAD.

\section{b. Suggestion}

With regard to things that are has been described above then can be given suggestions as the following:

1) For University of Merdeka Malang, it always maintains the information submitted to users and is always updating the information.

2) For future researchers, it is hoped that they can carry out research development using other independent variables such as system quality, so that they can have a better impact on user satisfaction.

\section{REFERENCES}

1. Petter, S., DeLone, William H., dan McLean, Ephraim R. (2013). Information Systems Success: The Quest for the Independent Variables. Journal of Information Systems, 29 (IV), 7-61.

2. William, Stanton, J. 2012. Principles of Marketing (translation). Erlangga. Jakarta.

3. Almazan A., Demian, Tovar Y.S. \& Quintero, J.M.M.. 2017. Influence of Information Systems on Organizational Results. Information System, 62 (2), 303-320.

4. Mahardika dan Basuki. 2011. Factor Determining Acceptance Level of Internet Banking implementation. Journal of Economics, Business, and Accountancy Ventura. Vol. 10 No. 1: 169-175.

5. Putra, I. P. A. P. A., I. Putu Gde Sukaatmadja, and I. G. K. Giantari. 2016. The Effect of Perceived Ease of Use, Perception of Risk on Trust and Intention to Buy E-tickets on the Traveloka Site. E-Journal of Economics and Business, Udayana University. 5.9: 3007-3030.

6. Rahmad, Andri Daisy, Endang Siti Astuti, and Ryadi. 2017. The Effect of Convenience on Trust and Use of SMS Banking (Study on Students of the Department of Business Administration Universities Brawijaya). Journal of Business Administration. Vol. 43 No 1: 36-43

7 Ginting, D. B., \& Marlina, M. R. 2017. Analysis of the Effect of System Quality, Service Quality, Information Quality, Ease of Use, and Perceptions of Benefits on User Satisfaction of E-Filing Facilities. Media Informatics, 16 (1): $20-31$.

8 Wijaya, Chandra and Sesilah Kempa. 2018. The Effect of Trust, Convenience, Quality of Information on Customer Satisfaction Through Purchasing Decisions of Fashion Products at Lazada. Agora. Volume 6 No 2.

9 Kadir, Abdul. 2010. Introduction to Information Systems. Andi, Yogyakarta.

10. De Lone, W.H., dan McLean, E.R. 2003. Information Systems Success: The Quest for the Dependent Variable. Information Systems Research, pp. 60-95.

11. Bodnar, George H and William S Hopwood, 2010. Accounting information system. ANDI Publisher, Yogyakarta.

12. Pambudi, Bambang Setiyo. 2014. The Effect of Perception of Benefits, Perceptions of Ease, Security, and Availability of Features on Bank Customers' Re-Interest in Using Internet Banking. Journal of Management Studies. Vol. 8, No. 1, 2014.

13. Priambodo dan Prabawani, B., 2016. The Effect of Perceptions of Benefits, Perceptions of Ease of Use, and Perceptions of Risk on Interest in Using Electronic Money Services (Case Study of Communities in Semarang City). Journal of Business Administration Science, Volume 5, Nomor 2.

14. Armanda, Ribka. 2015. Analysis of Acceptance Factors and Technology Use in Accounting Information Systems with the TAM Approach. Journal of Accounting Science \& Research, Vol. 4, No.3, 2015.

15. Lee, H.H., Fiore, A.M., and Kim, J., 2010, The role of the technology acceptance model in explaining effects of image interactivity technology on consumer responses. International Journal of Retail \& Distribution Management. Vol. 34 , No. 8. 
16. Sirdeshmukh, D., Singh, J., \& Sabol, B. 2002. Consumer Trust, Value, and loyalty in relational exchanges. Journal of Marketing Vol. 66 No. 1, 15-37.

17. Sam, F., \& Tahir, M. 2010. Website quality and consumer online purchase intention of air ticket. Melaka 75300 Malaysia: Technology Management Department, Faculty of Technology Management \& Technopreneurship. University of Technical Malaysia Melaka.

18. Mayer, R., David, J., \& Schoorman, F. 2005. An Integratif Model of Organizational Trus . Academy of Management Review No. 30 No. 3, 709-734.

19. Kotler, Philip dan Amstrong, Gary, (2014), Principles of Marketing, 12th Edition, Jilid 1 Terjemahan Bob Sabran Jakarta : Erlangga.

20. Lee Ally dan Yair Levy. 2014. The effect of information quality on trust in e-government systems' transformation, Transforming Government: People, Process and Policy. Vol. 8 Iss 1: 76 - 100.

21. Hadi, Syamsul., \& Novi. 2015. Factors Affecting the Use of Mobile Banking Services. Journal of Economics \& Development. Vol.5, No.1.

23. Utomo, Listanto Tri, Yusa Tomo Ardianto dan Nanik Sisharini. 2017. The Influence of System Quality, Information Quality, Service Quality, on User Satisfaction of Academic Information System Universitas Merdeka Malang. Journal of Information Technology \& Management. Volume 5 Nomor 2: 149-160.

24. Wahyudi, Farid, Harianto Respati dan Yusaq Tomo Ardianto. 2017. Study on DAPODIK Information System: User Satisfaction as Mediation of System Quality and Information Quality on Net benefit. Information and Knowledge Management. Vol.7, No.7: 53 - 62. 